\title{
Status of seed-borne fungi in some indigenous medicinal and aromatic plants conserved in National Gene Bank, India
}

\author{
JAMEEL AKHTAR ${ }^{1 *}$, BALESHWAR SINGH ${ }^{1}$, ARAVINDARAM KANDAN ${ }^{1}$, PARDEEP KUMAR ${ }^{1}$, ASHOK KUMAR \\ MAURYA ${ }^{1}$, DINESH CHAND ${ }^{2}$, VEENA GUPTA ${ }^{3}$ and SUNIL CHANDRA DUBEY ${ }^{1}$ \\ ${ }^{1}$ Division of Plant Quarantine, ${ }^{3}$ Division of Germplasm Conservation, ICAR-National Bureau of Plant Genetic Resources, New Delhi \\ 110012, India \\ 2ICAR-National Bureau of Plant Genetic Resources, Regional Station, PDKV Campus, Akola 444001 , Maharashtra, India
}

Received: 22 February 2017/ Accepted: 23 May 2017/ Published online: 25 May 2017

(C) Indian Phytopathological Society 2017

\begin{abstract}
During 2011-2015, seed health testing (SHT) of 880 accessions representing more than 60 crop species of medicinal and aromatic plants (MAPs) germplasm resulted in detection and identification of 17 fungal species belonging to 11 genera. Based on morphological key characteristics, various pathogens, namely Botrytis cinerea, Cephalosporium maydis, Colletotrichum gloeosporioides, Fusarium equiseti, F. oxysporum, F. semitectum, F. solani, F. verticillioides, Lasiodiplodia theobromae, Macrophomina phaseolina, Melanospora zamiae, Myrothecium roridum, M. verrucaria, Phoma exigua var. exigua, $P$. sorghina, Ustilago coicis and Verticillium albo-atrum were recorded on 71 accessions (8.1\%) of MAPs germplasm with varying level of seed infections (10-50\%). Pathogen wise overall infection showed the highest infection share of $U$. coicis (44.4\%) followed by $P$. sorghina (19.4\%) and B. cinerea $(11.1 \%)$ among 71 infected accessions. A perusal of literature indicated that detection of B. cinerea and M. roridum on Vernonia anthelmintica; $C$. maydis and M. verrucaria on Costus speciosus; C. gloeosporioides and M. phaseolina on Abroma augusta; F. equiseti on Origanum vulgare; F. verticillioides on C. speciosus, Mucuna pruriens and Trichosanthes cucumerina; $L$. theobromae on $C$. speciosus, T.cucumerina and T. bracteata; $P$. exigua var. exigua on $T$. cucumerina; and $P$. sorghina on Coix lacryma-jobi, C. speciosus, Ochna lanceolata, Perilla frutescens, Tagetus patula, T. cucumerina and $T$. bracteata are new host records on MAPs germplasm from India. If such infected seeds are conserved and/or distributed for either research purpose or their commercial use, they may act as a source of inocula dissemination and hamper the cultivation of MAPs leading to losses in quality and yield. Therefore, detection of seed infection through seed health testing is important in conserving disease-free material so as to minimize the risk of spreading disease in the country.
\end{abstract}

Keywords: Conservation, MAPs germplasm, seed health testing, seed-borne fungi

India has been considered as a treasure house of valuable MAPs/flora which constitutes an important natural wealth of our country as they play a significant role in providing primary health care services to the people. MAPs find a prime place in healthcare from ancient Indian Ayurveda, Siddha and Unani medical systems along with other schemes like homeopathic and allopathic systems (Gurib-Fakim, 2006). It is expected that sale of herbal medicines is likely to increase up to $\$$ US 3 trillion by 2020 (Schippmann et al., 2002). The increased global demand for MAPs by various processing industries like nutraceuticals, pharmaceutical, cosmetic, food, etc. have resulted in placing pressure on natural resources, since most species used are still collected from their wild habitat (Gupta et al., 2013). Due to climate change and uncontrolled over-exploitation of wild plants, there is habitat loss of MAPs, that's why their evaluation, utilization and conservation have become essential to fulfilling the future demand (Barata et al., 2016). Therefore, ICAR-National Bureau of Plant Genetic Resources (ICAR-NBPGR), New Delhi, India is

Corresponding author: jameel.akhtar@icar.gov.in undertaking exploration for indigenous MAPs germplasm collection with the aim of their safe conservation after SHT and utilization by providing germplasm worldwide.

Nutrient-rich seeds are a good nutritional substrate for the growth of various microorganisms, including pathogens. Pathogens which damaging the root, leaf and stem are transmitted through seeds or which inhabit the soil environment, decrease the aesthetic values of ornamentals crops (Gilbert, 2003; Kiecana et al., 2012). Infected seed is the primary source of inoculum for infection in seedlings.

Medicinal plants are also attacked by fungi, bacteria, viruses, phytoplasma/mollicutes, nematodes and some are notably notorious and lead to epidemics under favourable environment. Little attention towards the cause and their control has been given so far (Sinha et al., 2002). Various pathogens adversely affect the medicinal plant parts and decrease in the medicinal value. It may be harmful to the human body while using these infected plant parts as medicine (Chavan and Korekar, 2011). Review of literature reveals that pathogenic as well as 
saprophytic fungi predominantly colonize MAPs seeds (Raut et al., 2016). The most common saprophytic fungi colonizing seeds comprises Alternaria, Cladosporium, Rhizopus, Mucor, Aspergillus and Penicillium. Pathogenic fungi namely, Fusarium spp., Lasiodiplodia theobromae and Ustilago coicis etc. needs more attention among pathogenic fungi colonizing seeds because they produce toxins and enzymes which play an important role in the pathogenesis (Raut et al., 2016; Richardson, 1990; Titatarn et al., 1983). However, scanty information is available on pathogens of MAPs in the literature (Dev et al., 2010). Therefore, keeping in view the importance of MAPs germplasm, study was undertaken to assess their seed health status for their safe conservation in the National Gene Bank for future.

\section{MATERIALS AND METHODS}

The seeds of 880 accessions (Table 1) representing more than 60 genera of indigenously multiplied/collected MAPs germplasm from different agro-ecological zones of the country were received for SHT during 2011-2015. Seed health testing of MAPs germplasm was conducted in the Division of Plant Quarantine, ICAR-National Bureau of Plant Genetic Resources, New Delhi, India to detect and identify the fungal pathogens associated with them before conservation in the National Gene Bank. The seed samples of all the accessions were first examined visually and then abnormal, discoloured and deformed seeds etc. were subjected to blotter test (Mathur and Kongsdal, 2003).

The seeds were surface sterilized by immersing in $4.0 \% \mathrm{NaOCl}$ for 30 seconds, subsequent rinsing three times in sterilized distilled water under aspetic conditions using laminar air flow. Depending upon availability and size of seeds, $10-25$ seeds per Petri plate $(110 \mathrm{~mm})$ were placed at equidistance on three layers of sterilized moist blotters and labelled. The seeded plates were then incubated for 7 days at $22 \pm 1^{\circ} \mathrm{C}$ under alternating cycles of $12 \mathrm{~h}$ light and darkness. On $8^{\text {th }}$ day, the incubated seeds were observed under stereomicroscope (Nikon$\mathrm{SMZ} 1500$ ) at different levels of magnification ranging from $0.75 x$ to $11.25 x$ for detection of fungal

Table 1. List of medicinal and aromatic plants germplasm tested for seed-borne fungal pathogens.

\begin{tabular}{|c|c|c|c|}
\hline Common name & Botanical name & Common name & Botanical name \\
\hline Devil's cotton & Abroma agusta $(4)^{*}$ & Mallotus & Mallotus philippensis (1) \\
\hline Indian liquorice & Abrus precatorius (3) & Mallow & Malva spp. (3) \\
\hline Bead Tree & Adenanthera spp. (3) & Ice Plant & Martynia diandra (1) \\
\hline King of bitters & Andrographis paniculata (7) & Touch-me-not & Mimosa pudica (1) \\
\hline Indian birthwort & Aristolochia indica (1) & Four o'clock Plant & Mirabilis jalapa (1) \\
\hline Vetches & Asparagus racemosus (8) & Noni & Morinda spp. (66) \\
\hline Annato & Bixa orellana (2) & Drumstick & Moringa oleifera (1) \\
\hline Shivlingi & Bryonopsis laciniosa (1) & Kewanch & Mucuna spp. (7) \\
\hline Callicarpa & Callicarpa macrophylla (1) & Katharai & Ochna lanceolata (4) \\
\hline Bhang & Cannabis sativa (1) & Basil & Ocimum spp. (80) \\
\hline Bittercress & Cardamine oligosperma (1) & Oregano & Origanum vulgare (32) \\
\hline Caraway & Carum spp. (14) & Broken bones plant & Oroxylum indicum (2) \\
\hline Jyotismati & Celasrtus paniculatus (2) & Amrul & Oxalis corniculata (1) \\
\hline Centratherum & Centratherum anthelminticum (1) & Ranghevada & Paracalyx scariosa (1) \\
\hline Safed Musli & Chlorophytum borivilianum (1) & Perilla & Perilla frutescens (4) \\
\hline Spider flower & Cleome viscose $(7)$ & Aonla & Phyllanthus emblica (1) \\
\hline Glorybower & Clerodendron viscosum (1) & Isabgol & Plantago ovate (28) \\
\hline Tear grass & Coix lacryma-jobi (402) & Common purslane & Portulaca oleracea (1) \\
\hline Kemuk & Costus speciosus (6) & Round galangal & Premna herbacea (1) \\
\hline Palmarosa grass & Cymbopogon martini (3) & Raspberry & Rubus ellipticus (1) \\
\hline Datura & Datura spp. (3) & Sage/ chia & Salvia hispanica (2) \\
\hline Persimmon tree & Diospyros melanoxylon (1) & Soapberry & Sapindus mukorossi (1) \\
\hline Malaysian apple & Diplocyclos palmatus (3) & Chirayata & Swertia spp. (6) \\
\hline False black pepper & Embelia ribes (1) & Tephrosia & Tephrosia purpurea (3) \\
\hline Brilliant gardenia & Gardenia resinifera (1) & Myrobalan & Terminalia spp. (2) \\
\hline Henbane & Hyoscyamus niger (1) & Ban Kapas & Thespesia lampas (1) \\
\hline Indigofera & Indigofera tinctoria (1) & Desert horse purslane & Trianthema portulacastrum (3) \\
\hline Lagerstroemia & Lagerstroemia parviflora (2) & Snake gourd & Trichosanthes spp. (107) \\
\hline Leea & Leea macrophylla (1) & Kalijiri & Vernonia anthelmintica (5) \\
\hline Leucaena & Leucaena leucocephala (1) & Ashwagandha & Withania somnifera (28) \\
\hline
\end{tabular}

*Values in parentheses show number of accessions. 
fructification(s) associated with seeds, if any. The slides were also prepared by mounting with lactophenol cotton blue stain for identification of fungus and observed under compound microscope (Nikon - Eclipse 80i). Further, to establish the identity of causal fungus, pure culture of the associated fungus was obtained on potato dextrose agar (PDA) by transferring its single spore grown on seeds (Akhtar et al., 2014). The observations on frequency of fungal infection and seed germination were recorded and correlation analysis was done. DIVA-GIS 7.5.0 software was used to point data into grid analysis using simple-circular neighborhood methods (Hijmans et al., 2001) and diversity was calculated using ShannonWiener diversity index (Magurran, 1988).

\section{RESULTS AND DISCUSSION}

Visual examination of SHT ensured detection of Ustilago coicis Bref., a smut fungus, in 32 accessions of Coix lacryma-jobi (IC-006645, IC-006667, IC-012637, IC012639, IC-012703, IC-089381, IC-089382, IC-089383, IC-089384, IC-089387, IC-089389, IC-089391, IC089392, IC-204184, IC-340015, IC-374506, IC-416971, IC-418897, IC-521338, IC-521339, IC-521341, IC521343, IC-540173, IC-540181, IC-540222, IC-540244, IC-540256, IC-540266, IC-540267, IC-540279) collected from Shillong, Meghalaya and RS/RS-I-20-2011 and RS/ RS-I-32-2011 from New Delhi. This disease is reported to cause yield loss of $12-25 \%$ and is widespread in Assam (Choudhary, 1946). Titatarn et al. (1983) also reported yield loss due to $U$. coicis ranging from $15-98 \%$ in Thailand.

After 7 days of incubation, critical examination of MAPs germplasm seeds under the stereozoom microscope at different levels of magnification resulted in detection and identification of 16 species belonging to 10 fungal genera of economic importance. Based on the growth characteristic and fruiting structures observed on seed/seedlings as described by Mathur and Kongsdal (2003) and IMI descriptions for fungi and bacteria, the associated fungi were identified as Botrytis cinerea Pers. Fr., Cephalosporium maydis Samra, Sabet \& Hingorani, Colletotrichum gloeosporioides (Penz.) Penz. \& Sacc., Fusarium equiseti (Corda) Sacc. (tel.: Gibberella intricans Wollenw.), F. oxysporum Schlechtendahl, F. semitectum Berk. \& Rav., F. solani (Martius) Sacc., F. verticillioides (Sacc.) Nirenberg (syn.: F. moniliforme Sheldon), Lasiodiplodia theobromae (Pat.) Griffiths \& Maubl. (syn.: Botryodiplodia theobromae), Macrophomina phaseolina (Tassi) Goid (syn.: Rhizoctonia bataticola), Melanospora zamial Corda, Myrothecium roridum Tode ex Fr., M. verrucaria, Phoma exigua var. exigua Desm. (syn.: P. herbarum), P. sorghina (Sacc.) Boerema Dorenbosch \& van Kest. (syn.: P. insidiosa), Verticillium albo-atrum Reinke \& Berthold in 39 accessions of 12 species belonging to 10 MAPs genera (Table 2).

Botrytis cinerea, a phytopathogenic fungus, was detected on seeds of three accessions of Costus speciosus from Bokaro (IC-439154) and Giridih (IC-
587520) of Jharkhand and Purulia (IC-336849) of West Bengal, in Mucuna pruriens (IC-613962) from Valsad, Gujarat, Ocimum sanctum (IC-612500) from Ganjam, Odisha and Vernonia anthelmintica (IC-587521) (Fig. 1a) from Ranchi, Jharkhand and on two accessions of Perilla frutescens from Ukhrul, Manipur (IC-615362) and Kohima, Nagaland (KCB3) with varying level of infection ranging from $10-20 \%$ (Table 3 ). It causes botrytis rot and gray mould in over 200 plant species of economic importance including grain legumes (Pande et al., 2006). Seed germination was also affected by this fungus which ranged from $0-90 \%$. It is very difficult to assess the damage caused by B. cinerea. However, economic losses of $>50 \%$ may occur in many crops, depending on the prevailing environmental conditions (CAB International, 2007).

Cephalosporium maydis, a fungus causing black bundle disease/late wilt of maize, seed rot, etc., was detected in one accession (IC-587520) of Costus speciosus from Jharkhand with $20 \%$ infection, which is internally and externally seed-borne pathogen on limited host comprising maize, cotton and lupins with limited geographical distribution including India. Its widespread incidence and severity of $100 \%$ infection have been reported in some fields (Samra et al., 1963).

Colletotrichum gloeosporioides, a causal agent of anthracnose/ fruit rot, was detected (10\% infection) in only one accession (IC-331486) of Abroma augusta (Fig. 1c) from Kolkata, West Bengal. This fungus causes a highly destructive anthracnose/ fruit-rot disease on a wide variety of monocotyledonous plants to higher dicotyledonous trees (Nelson, 2008). It causes considerable damage to a large number of crops such as cereals, legumes, and tropical, subtropical fruit crops including banana, coffee mango, etc., (Sharma and Kulshrestha, 2015).

Fusarium equiseti, the causal organism of dampingoff, stalk rot, post-harvest decay, etc., was detected and identified with $40 \%$ infection from seeds of one accession (IC-589099) of Origanum vulgare (Fig. 1b) from Uttarakhand. F. equiseti is associated with more than 50 crops species including Helianthus annuus, Brassica oleracea var. capitata, Capsicum annum, Cuminum cyminum, Glycine max, Oryza sativa, Solanum lycopersicum, S. tuberosum, Sorghum bicolor, Triticum aestivum, Vicia faba and Zea mays, etc., across the world (CAB International, 2007). The fungus is considered as a weak parasite. However, it could cause serious damage and high losses between $10-45 \%$ to seedling in commercial nurseries.

Fusarium oxysporum, the destructive wilt pathogen was detected with $100 \%$ infection level in two samples viz., KP/BA-1976 and KP/BA-2004 of Trichosanthes bracteata collected from Visakhapatnam and West Godavari, Andhra Pradesh, respectively. Losses caused by this fungus is not available in the literature. However, Janardhan et al. (1964) reported Fusarium wilt due to Fusarium oxysporum f. sp. rauvolfiae from Jammu. Medicinal plant species of Swertia chirayita, Rauvolfia 
Table 2. Morphological features of fungi detected in medicinal and aromatic plants germplasm

\begin{tabular}{|c|c|c|c|c|}
\hline \multirow[t]{2}{*}{ Fungus } & \multicolumn{4}{|c|}{ Growth characteristics } \\
\hline & Shape/type & Septation & Dimension & Attachment \\
\hline Botrytis cinerea & $\begin{array}{l}\text { Conidiophores with } \\
\text { characteristic 'twisting' } \\
\text { at several places }\end{array}$ & $\begin{array}{l}\text { Single-celled with slight } \\
\text { protuberant hilum }\end{array}$ & $\begin{array}{l}\text { Length } 8.0-14.0 \mu \mathrm{m} \\
\text { and width } 6-9 \mu \mathrm{m}\end{array}$ & $\begin{array}{l}\text { Ashgrey to greyish clusters } \\
\text { of conidia at several places } \\
\text { of conidiophores }\end{array}$ \\
\hline $\begin{array}{l}\text { Cephalosporium } \\
\text { maydis }\end{array}$ & $\begin{array}{l}\text { Conidia hyaline, ellipsoidal } \\
\text { to cylindrical, straight with } \\
\text { rounded ends }\end{array}$ & Conidia single-celled & $\begin{array}{l}\text { Length } 3.0-10.0 \mu \mathrm{m} \text { and } \\
\text { width } 1.5-3.0 \mu \mathrm{m}\end{array}$ & $\begin{array}{l}\text { Conidia in the form of shiny, } \\
\text { round and watery heads } \\
\text { attached perpendicular to } \\
\text { conidiophores }\end{array}$ \\
\hline
\end{tabular}

Colletotrichum Acervuli sub-epidermal gloeosporioides emerging by disrupting outer epidermis of the seed

$\begin{array}{ll}\text { Fusarium } & \text { Macroconidia hyaline, } \\ \text { equiseti } & \text { falcate with pedicellate } \\ & \text { foot cell attaining apical } \\ \text { cell inward }\end{array}$

Fusarium Microconidia oval, elliptical oxysporum or reniform and macroconidia falcate along with chlamydospores

$\begin{array}{ll}\text { Fusarium } & \text { Macroconidia hyaline, } \\ \text { semitectum } & \text { straight to slightly curved, } \\ & \text { wedg-shaped without } \\ \text { pedicellate basal cell }\end{array}$

Fusarium solani Microconidia hyaline, oval, ellipsoidal or reniform and macroconidia thick-walled, hyaline with short rounded apical cell

\begin{tabular}{|c|c|}
\hline $\begin{array}{l}\text { Fusarium } \\
\text { verticillioides }\end{array}$ & $\begin{array}{l}\text { Microconidia mostly } \\
\text { crescent shaped and } \\
\text { macroconidia fusoid with } \\
\text { sharply curved pedicellate } \\
\text { basal cell }\end{array}$ \\
\hline $\begin{array}{l}\text { Lasiodiplodia } \\
\text { theobromae }\end{array}$ & $\begin{array}{l}\text { Pycnidia brown to dark } \\
\text { brown }\end{array}$ \\
\hline $\begin{array}{l}\text { Macrophomina } \\
\text { phaseolina }\end{array}$ & $\begin{array}{l}\text { Dark brown to black } \\
\text { coloured large pycnidia } \\
\text { grown with mycelium } \\
\text { surrounding the neck of } \\
\text { the pycnidia }\end{array}$ \\
\hline $\begin{array}{l}\text { Melanospora } \\
\text { zamia }\end{array}$ & $\begin{array}{l}\text { Perithecia produced } \\
\text { superficially on seed } \\
\text { surface with leon-shaped } \\
\text { ascospore oozing from } \\
\text { neck }\end{array}$ \\
\hline $\begin{array}{l}\text { Myrothecium } \\
\text { roridum }\end{array}$ & $\begin{array}{l}\text { Conidia hyaline to light } \\
\text { green and cylindrical with } \\
\text { slightly rounded end }\end{array}$ \\
\hline $\begin{array}{l}\text { Myrothecium } \\
\text { verrucaria }\end{array}$ & $\begin{array}{l}\text { Conidia hyaline to olive } \\
\text { green, elliptical with } \\
\text { pointed end }\end{array}$ \\
\hline
\end{tabular}

Phoma exigua Pycnidia brown to black, var. exigua slightly embedded in seed coat
Setae dark brown, rigid, swollen at the base, slightly tapered to the paler acute apex, 1 to 5-septate, $250 \times 6 \mu \mathrm{m}$

Macroconidia mostly non Macroconidia 22.0septate and macroconidia $60.0 \mu \mathrm{m}$ long and 3.0mostly 5 septate, but sometimes 3 to 5 -septate 23.0 and width 3.0-5.0 $\mu \mathrm{m}$

Conidia hyaline, with narrow Microconidia mostly non septate and macroconidia mostly 3-septate, sometimes 3-5 septate

Macroconidia mostly
$3-5$ septate $6.0 \mu \mathrm{m}$ wide

Microconidia 5-12 $\mu \mathrm{m}$ long and 2-3.5 $\mu \mathrm{m}$ wide; macroconidia mostly 27-65 $\mu \mathrm{m}$ long and 3-5 $\mu \mathrm{m}$ wide

Macroconidia 17.0-40.0 $\mu \mathrm{m}$ long and 2.0-4.0 $\mu \mathrm{m}$ wide

Microconidia mostly $0-1$ septate and macroconidia mostly 3-4 septate

Microconidia 8-15 $\mu \mathrm{m}$ long and 2-4 $\mu \mathrm{m}$ wide, macroconidia mostly 45.0-100 $\mu \mathrm{m}$ long and 5-8 $\mu \mathrm{m}$ wide

Microconidia occasionally Microconidial length 5-12 one-septate and macro- $\mu \mathrm{m}$ and width1.5-2.5 $\mu \mathrm{m}$, conidia mostly 3 septate macroconidia mostly 25$60.0 \mu \mathrm{m}$ long and $2.5-4$ $\mu \mathrm{m}$ width

Non-septate, hyaline, sometimes guttulate

Spores non-septate, hyaline, ellipsoide to obovoid

Conidial dimension ranged between 3.5-4.5 $x 1.5 \mu \mathrm{m}$

Spore size measured $15.0-30.0 \times 5.0-10.0 \mu \mathrm{m}$

Single-celled citriform and dark brown to blackish ascospores

Conidia single-celled

Conidia single-celled

Conidia non-septate, hyaline, mostly straight and guttulate, cylindrical
Conidial dimension measured between 15.0$25.0 \times 11-15 \mu \mathrm{m}$

Conidial size measured 5.0-7.0 x 1.0-2.0 $\mu \mathrm{m}$

Conidial size measured 5.0-7.0 x 2.5-3.5 $\mu \mathrm{m}$

Conidial dimension ranged between 5.0$10.0 \times 2.5-3.0 \mu \mathrm{m}$ truncate base, aseptate, uninucleate

Macroconidia produced in creamy or organge coloured slimy mass, called as 'pinnotes' on seed

Microconidia formed in false-heads on monophialides macroconidia in slimy mass

Branch conidiophores/ phialides bear single macroconidia, sometimes conidia in pinnotes giving flower like structure.

Microconidia formed in translucent to opaque, milky white watery drops on long phialides; macroconidia produced in cream coloured sporodochia

Microconidia in chains and macroconidia in wet mass

Pycnidia erumpent with silvery white mycelium

Spores oozing from osteole in white cooured cirrhus

Spores oozing from the neck in black cooured longvery long cirrhus

Spores formed in blackish green to black sporodochia on seed surface

Spores formed in irregularshaped, green to dark green, flat sporodochia on seed surface

Conidia produced in pycnidia embedded in seed coat

Contd... 


\begin{tabular}{|c|c|c|c|c|}
\hline \multirow[t]{2}{*}{ Fungus } & \multicolumn{4}{|c|}{ Growth characteristics } \\
\hline & Shape/ type & Septation & Dimension & Attachment \\
\hline Phoma sorghina & $\begin{array}{l}\text { Profuse mycelium, } \\
\text { pycnidia black and shiny } \\
\text { with small to long neck }\end{array}$ & $\begin{array}{l}\text { Non-septate, hyaline, } \\
\text { cylindrical and guttulate } \\
\text { conidia }\end{array}$ & $\begin{array}{l}\text { Conidial dimension } \\
\text { ranged between 3-7 x } \\
2-2.5 \mu \mathrm{m}\end{array}$ & $\begin{array}{l}\text { Conidia produced in } \\
\text { superficially developed } \\
\text { pycnidia on aerial mycelium }\end{array}$ \\
\hline Ustilago coicis & $\begin{array}{l}\text { Mass of teliospores of dark } \\
\text { brown colour, sub-globose } \\
\text { to ellipsoidal in shape with } \\
\text { minute echinulations giving } \\
\text { the margin a serrated } \\
\text { appearance }\end{array}$ & $\begin{array}{l}\text { Teliospore germinates } \\
\text { into 4-celled } \\
\text { promycelium. }\end{array}$ & $\begin{array}{l}\text { The teliospores } \\
\text { dimension ranged } \\
\text { between } 7.0-14.0 \mu \mathrm{m} \\
\text { in diameter }\end{array}$ & $\begin{array}{l}\text { Sporidia formed terminally } \\
\text { as well as laterally near the } \\
\text { septa }\end{array}$ \\
\hline $\begin{array}{l}\text { Verticillium } \\
\text { albo-atrum }\end{array}$ & $\begin{array}{l}\text { Verticils of phialieds } \\
\text { bearing small colourless, } \\
\text { circular, shiny watery } \\
\text { drops at the tips of each } \\
\text { vertical }\end{array}$ & $\begin{array}{l}\text { Single-celled, } \\
\text { occasionally } 1 \text {-septate }\end{array}$ & 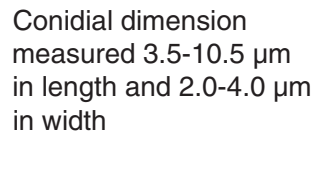 & $\begin{array}{l}\text { Verticils of phialides } \\
\text { arranged erect on } \\
\text { conidiophores }\end{array}$ \\
\hline
\end{tabular}
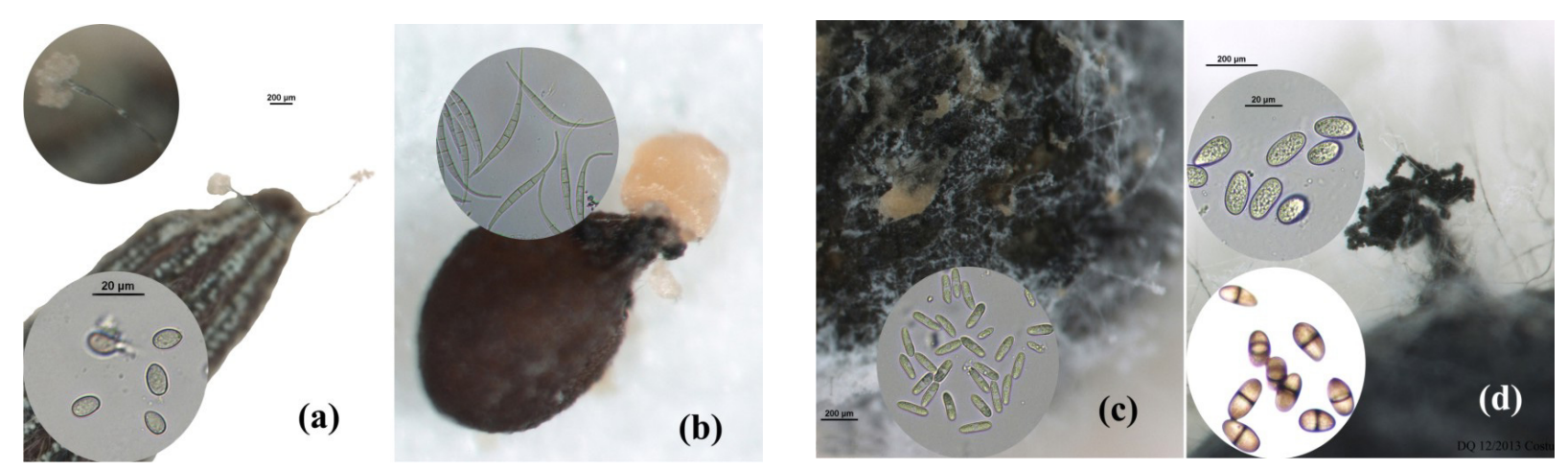

Fig. 1. Important seed-borne fungi detected on medicinal and aromatic crops; (a) Botrytis cinerea on Vernonia anthelmintica, (b) Fusarium equiseti on Origanum vulgare, (c) Colletotrichum gloeosporioides on Abroma augusta and (d), Lasiodiplodia theobromae on Costus speciosus

serpentina, Lavandula angustifolia and Aloe barbadensis have also been reported severely infected with wilt from Himachal Pradesh, India by Chandel et al. (2014).

Fusarium semitectum, the causal agent of diseases like wilts, blights, root rots, and cankers in coffee, pine trees, wheat, corn, rice, cereals, carnations and grasses was detected in three accessions of Costus speciosus (IC-336849 from Purulia, West Bengal; IC-439154 from Bokaro and IC-587520 from Giridih, Jharkhand) and in one accessions of Coix lacryma-jobi (IC-435150) from Dumka, Jharkhand with varying infection level ranged between $70-90 \%$. The pathogen is both externally and internally seed-borne. The internal inoculum affects seed germination, viability and caused high losses (pre- and post-emergence) from 15 to $75 \%$. Gupta et al. (2011) have reported heavy losses to the Shisham tree plantation due to its transmission from seed to seedling. Ingle and Rai (2011) have reported genetic diversity among Indian phytopathogenic isolates of F. semitectum.

Fusarium solani, causes wilt and damping-off disease on a number of crop species, was detected in two accessions of Costus speciosus (IC-336849 from Purulia, West Bengal and IC-587520 from Giridih, Jharkhand) and two accessions of Trichosanthes cucumerina (IC-618003 from Udham Singh Nagar,
Uttrakhand and IC-596997 from Changlang, Arunachal Pradesh) with infection level of $10-20 \%$. F. solanicauses substantial economic losses worldwide including wilt of Lavandula angustifolia in India (Chandel et al., 2014). Moreover, molecular studies revealed a high level of diversity within the fungal population (Saremi et al., 2011).

Fusarium verticillioides, the causal organism of bakane/stalk/stem/ear rots diseases, was detected in one accession each of Coix lacryma-jobi (IC-089385) from Shillong, Meghalaya and Costus speciosus (IC-587520) from Giridih, Jharkhand and two accessions each of Mucuna pruriens (SKMP-15 from Rangpoh, Sikkim and RJSSMP-07 from Jhalawar, Rajasthan) and T. cucumerina (KP/NSP1430 and KP/NSP1441) from Udham Singh Nagar, Uttrakhand with average infection level of $10-30 \%$. This fungus is reported to cause huge yield losses up to $75 \%$ in rice from Iran (Saremi et al., 2008) and also has genetic variability (Sharma et al., 2014).

Lasiodiplodia theobromae, a plurivorous and secondary pathogen, was detected during incubation test in one accession each of Costus speciosus (IC-439154) from Bokaro, Jharkhand (Fig. 1d), Tricosanthes bracteata (KP/BA-2018) from West Godavari, Andhra Pradesh and Trichosanthes cucumerina (IC-618003) from Udham Singh Nagar, Uttrakhand and in three accessions of 
Table 3. Important seed-borne fungi detected on seeds of some indigenous medicinal and aromatic plants germplasm

\begin{tabular}{|c|c|c|c|}
\hline Pathogen & Crop & Accession/ infection (\%) & Source \\
\hline \multirow[t]{5}{*}{ Botrytis cinerea } & Costus speciosus & $\begin{array}{l}\text { IC-439154 (20\%) } \\
\text { IC-336849 (10\%) } \\
\text { IC-587520 (10\%) }\end{array}$ & $\begin{array}{l}\text { Bokaro, Jharkhand } \\
\text { Purulia, West Bengal } \\
\text { Giridih, Jharkhand }\end{array}$ \\
\hline & Mucuna pruriens & IC-613962 (20\%) & Valsad, Gujarat \\
\hline & Ocimum sanctum & IC-612500 (10\%) & Ganjam, Odisha \\
\hline & Perilla frutescens & $\begin{array}{l}\text { IC-615362 (10\%) } \\
\text { KCB3 (10\%) }\end{array}$ & $\begin{array}{l}\text { Ukhrul, Manipur } \\
\text { Kohima, Nagaland }\end{array}$ \\
\hline & Vernonia anthelmintica & IC-587521 (30\%) & Ranchi, Jharkhand \\
\hline Cephalosporium maydis & C. speciosus & IC-587520 (20\%) & Giridih, Jharkhand \\
\hline Colletotrichum gloeosporioides & Abroma augusta & IC-331486 (10\%) & Kolkata,West Bengal \\
\hline Fusarium equiseti & Origanum vulgare & IC-589099 (40\%) & Pauri, Uttrakhand \\
\hline F. oxysporum & Trichosanthes bracteata & $\begin{array}{l}\text { KP/BA-1976 (100\%) } \\
\text { KP/BA-2004 (100\%) }\end{array}$ & $\begin{array}{l}\text { Visakhapatnam, Andhra Pradesh } \\
\text { West Godavari, Andhra Pradesh }\end{array}$ \\
\hline \multirow[t]{2}{*}{ F. semitectum } & C. speciosus & $\begin{array}{l}\text { IC-336849 (70\%) } \\
\text { IC-439154 (80\%) } \\
\text { IC-587520 (90\%) }\end{array}$ & $\begin{array}{l}\text { Purulia, West Bengal } \\
\text { Bokaro, Jharkhand } \\
\text { Giridih, Jharkhand }\end{array}$ \\
\hline & Coix lacryma-jobi & IC-435150 (80\%) & Dumka, Jharkhand \\
\hline \multirow[t]{2}{*}{ F. solani } & C. speciosus & $\begin{array}{l}\text { IC-336849 (20\%) } \\
\text { IC-587520 (10\%) }\end{array}$ & $\begin{array}{l}\text { Purulia, West Bengal } \\
\text { Giridih, Jharkhand }\end{array}$ \\
\hline & Trichosanthes cucumerina & $\begin{array}{l}\text { IC-618003 (20\%) } \\
\text { IC-596997 (10\%) }\end{array}$ & $\begin{array}{l}\text { Udham Singh Nagar, Uttrakhand } \\
\text { Changlang, Arunachal Pradesh }\end{array}$ \\
\hline \multirow[t]{5}{*}{ F. verticillioides } & C. lacryma-jobi & IC-089385 (10\%) & Shillong, Meghalaya \\
\hline & C. speciosus & IC-587520 (20\%) & Giridih, Jharkhand \\
\hline & M. pruriens & SKMP-15 (20\%) & Rangpoh, Sikkim \\
\hline & & RJSSMP-07 (30\%) & Jhalawar, Rajathan \\
\hline & T. cucumerina & $\begin{array}{l}\text { KP/NSP1430 (20\%), } \\
\text { KP/NSP1441 (10\%) }\end{array}$ & Udham Singh Nagar, Uttrakhand \\
\hline \multirow[t]{4}{*}{ Lasiodiplodia theobromae } & C. speciosus & IC-439154 (10\%) & Bokaro, Jharkhand \\
\hline & T. bracteata & KP/BA-2018 (100\%) & West Godavari, Andhra Pradesh \\
\hline & T. cucumerina & IC-618003 (40\%) & Udham Singh Nagar, Uttrakhand \\
\hline & Trichosanthes sp. & $\begin{array}{l}\text { IC-539383, IC-539384, } \\
\text { IC-539386 (100\% each) }\end{array}$ & Nainital, Uttrakhand \\
\hline Macrophomina phaseolina & A. augusta & IC-557342 (30\%) & Kolkata, West Bengal \\
\hline Melanospora zamiae & C. speciosus & IC-587520 (20\%) & Giridih, Jharkhand \\
\hline Myrothecium roridum & V. anthelmintica & $\begin{array}{l}\text { IC-572783 (10\%) } \\
\text { IC-587521 (20\%) }\end{array}$ & $\begin{array}{l}\text { Solan, Himachal Pradesh } \\
\text { Ranchi, Jharkhand }\end{array}$ \\
\hline M. verrucaria & C. speciosus & IC-439154 (10\%) & Bokaro, Jharkhand \\
\hline Phoma exigua var. exigua & T. cucumerina & KP/NSP1430 (40\%) & Udham Singh Nagar, Uttrakhand \\
\hline \multirow[t]{8}{*}{ P. sorghina } & C. lacryma-jobi & IC-435150 (40\%) & Dumka, Jharkhand \\
\hline & & $\begin{array}{l}\text { IC-089385 and IC-416826 } \\
\text { (10\% each), IC-524661, } \\
\text { IC-540267 (20\% each) }\end{array}$ & Shillong, Meghalaya \\
\hline & C. speciosus & $\begin{array}{l}\text { IC-439154 (20\%) } \\
\text { IC-587520 (20\%) }\end{array}$ & $\begin{array}{l}\text { Bokaro, Jharkhand } \\
\text { Giridih, Jharkhand }\end{array}$ \\
\hline & Ochna lanceolata & IC-373679 (10\%) & Kottayam, Kerala \\
\hline & P. frutescens & $\begin{array}{l}\text { RS/RS-I-2-2011 (10\%) } \\
\text { SHL1316 (50\%) }\end{array}$ & $\begin{array}{l}\text { Kohima, Nagaland } \\
\text { Ukhrul, Manipur }\end{array}$ \\
\hline & Tagetes patula & IC-318942 (30\%) & Nainital, Uttrakhand \\
\hline & T. cucumerina & DPP-10-41 (30\%) & Boudh, Odisha \\
\hline & T. bracteata & $\begin{array}{l}\text { IC-539383, IC-539385 } \\
\text { (100\% each) }\end{array}$ & Nainital, Uttrakhand \\
\hline \multirow[t]{3}{*}{ Verticllium albo-atrum } & T. bracteata & KP/BA-1977 (10\%) & Vizianagaram, Andhra Pradesh \\
\hline & M. pruriens & SKMP-15 (20\%) & Rangpoh, Sikkim \\
\hline & & IC-615378 (10\%) & Ukhrul, Manipur \\
\hline
\end{tabular}


Trichosanthes sp. (IC-539383, IC-539384 and IC539386) from Nainital, Uttrakhand with infection level of $10-100 \%$. It has been found to affect a wide range of hosts including more than 40 host crops causing numerous diseases such as fruit rot of coconut, leaf blight of Pandanus odoratissimus, the rot of cashew kernel, seedling mortality of maize, etc. (Punithalingam, 1980). In addition, seed rot and blackening of seeds has also been reported to affect seed germination, viability and vigour (Gure et al., 2005, Nwachukwu and Umechuruba, 1996).

Macrophomina phaseolina, the causal agent of charcoal rot, ashy stem blight and root rot in a variety of crops, was detected in one accession (IC-557342) of Abroma augusta (Fig. 2a) from Kolkata, West Bengal with $30 \%$ infection level. A yield loss of $31-38 \%$ has been reported in sorghum from India due to this fungus (CAB International, 2007). Mahdizadeh et al. (2011) reported high levels of variability within M. phaseolina.

Melanospora zamiae, the causal agent of crown rust of maize was detected in only one accession (IC-587520) of $C$. speciosus from Giridih, Jharkhand. The report of the Technical Working Group 1 of Australia listed this as a pathogen of quarantine significance and highlighted the risk associated with the bulk maize import from USA (Irwin et al., 1999).

Myrothecium roridum, a cosmopolitan plant pathogen with a broad host range causing blight, leaf spot, ring rot and stem necrosis, was detected with 10$20 \%$ infection level in two samples of Vernonia anthelmintica (Fig. 2b) from Ranchi, Jharkhand (IC587521) and Solan, Himachal Pradesh (IC-572783). It infects a large number of plant hosts, including vegetables, fruits and ornamental plants (Hong et al., 2013; Okunowo et al., 2010).

Myrothecium verrucaria, a fungus causing leaf spot, blotch and blight in a various crop species, was detected in only one accession (IC-439154) of Costus speciosus from Jharkhand with infection level of $10 \%$. Mucuna verrucaria has been reported to infect many hosts viz., Allium cepa, Arachis hypogaea, Avena sativa, Capsicum spp., Coffea spp., Gossypium spp., Morus sp., Nicotiana

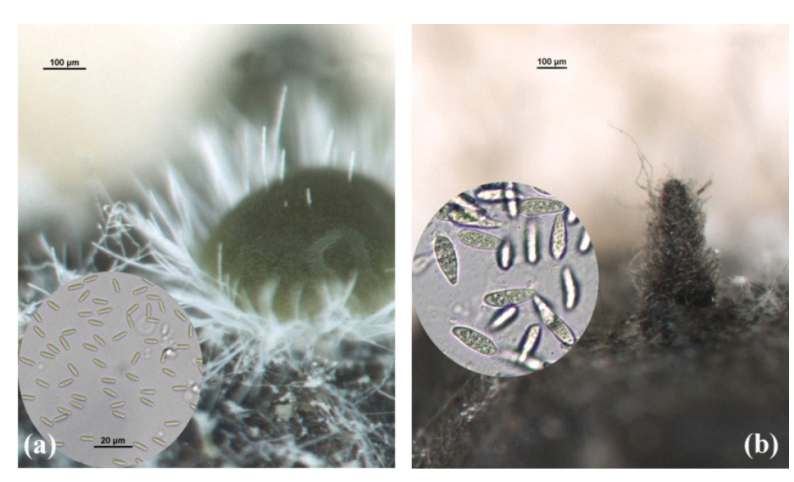

Fig. 2. Macrophomina phaseolina detected on Abroma augusta (a) and Myrothecium roridum on Vernonia Anthelmintica (b) tabacum, Pennisetum glaucum, Phaseolus vulgaris, etc. (Yang, 1995).

Phoma exigua var. exigua, a fungus causing leaf spot/leaf blotch/root rot/tuber rot, was detected in one accession of Trichosanthes cucumerina (KP/NSP1430) from Udham Singh Nagar, Uttarakhand with seed infection of $40 \%$. This fungus is a ubiquitous weak or secondary pathogen, which infects more than 200 different plant genera worldwide (CAB International, 2007).

Phoma sorghina, a weak pathogen, causes leaf spot, glume blight in several grasses, was detected in 14 accessions of C. lacryma-jobi (IC-435150 from Dumka, Jharkhand, IC-089385, IC-416826, IC-524661 and IC-540267 from Shillong, Meghalaya), in Costus speciosus (IC-439154 from Bokaro, IC-587520 from Giridih, Jharkhand), in Ochna lanceolata (IC-373679 from Kottayam, Kerala), in Perilla frutescens (RS/RSI-2-2011 from Kohima, Nagaland, SHL1316 from Ukhrul, Manipur), in Tagetus patula (IC-318942 from Nainital, Uttrakhand) and in T. cucumerina (DPP-10-41 from Boudh, Odisha and T. bracteata (IC-539383 and IC539385) from Nainital, Uttrakhand with varying degree of infection ranging from $10-100 \%$. P. sorghina has a wide host range with worldwide distribution (Singh et al., 2014). Yield losses up to $14 \%$ due to glume blight caused by $P$. sorghina in rice has been reported and the pathogen was earlier considered to be of minor economic importance but attained epidemic proportions over a large geographical area during 1979-80 (Prabhu and Bedendo, 1988).

Verticillium albo-atrum, a causal agent of verticillium wilt disease in several crops, was detected in T. bracteata (KP/BA-1977) from Vizianagaram, Andhra Pradesh and in M. pruriens (SKMP-15 from Rangpoh, Sikkim, and IC615378 from Ukhrul, Manipur) with infection level of 10.0$20.0 \%$ ). A yield loss of $10-15 \%$ in rockwool crop, with occasional dead plants; and $20-25 \%$ plant death has been reported in rockwool, hydrophonics and soil-grown crops (CAB International, 2007).

Keeping in view occurrence of the above-mentioned pathogens and resulting yield losses in crops other than MAPs as well as the existence of genetic variability in them, the detection and identification of 17 fungal species belonging to 11 genera in 12 species of medicinal and aromatic crops could be a potential threat in future for their cultivation.

As per perusal of literature, there is no record of Botrytis cinerea and Myrothecium roridum on Vernonia anthelmintica; Cephalosporium maydis and Myrothecium verrucaria on Costus speciosus; Colletotrichum gloeosporioides and Macrophomina phaseolina on Abroma augusta; Fusarium equiseti on Origanum vulgare; Fusarium verticillioides on Costus speciosus, Mucuna pruriens and Trichosanthes cucumerina; Lasiodiplodia theobromae on Costus speciosus $T$. cucumerina and T. bracteata; Phoma exigua var. exigua on T. cucumerina and T. bracteata and Phoma sorghina 


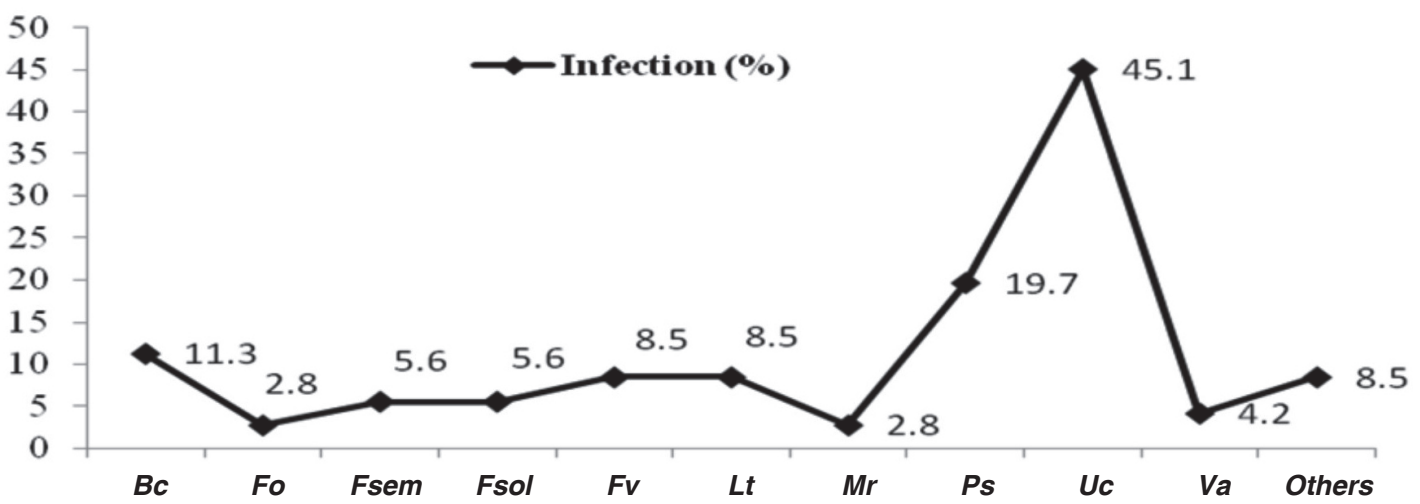

Fig. 3. Pathogen-wise fungal infection (\%) detected in medicinal and aromatic plants germplasm. (Bc= Botrytis cinerea; $\mathrm{Cm}=$ Cephalosporium maydis; Fo= Fusarium oxysporum; Fsem= F. semitectum; Fsol= F. solani; Fv= F. verticillioides; $L t=L a s i o d i p l o d i a$ theobromae; $\mathrm{Mr}=$ Myrothecium roridum; $P \mathrm{~S}=$ Phoma sorghina; $\mathrm{Va}=$ Verticillium albo-atrum). Other pathogens include Colletotrichum gloeosporioides, Fusarium equiseti, Macrophomina phaseolina, Melanospora zamiae, Myrothecium Verrucaria and Phoma exigua var. exigua

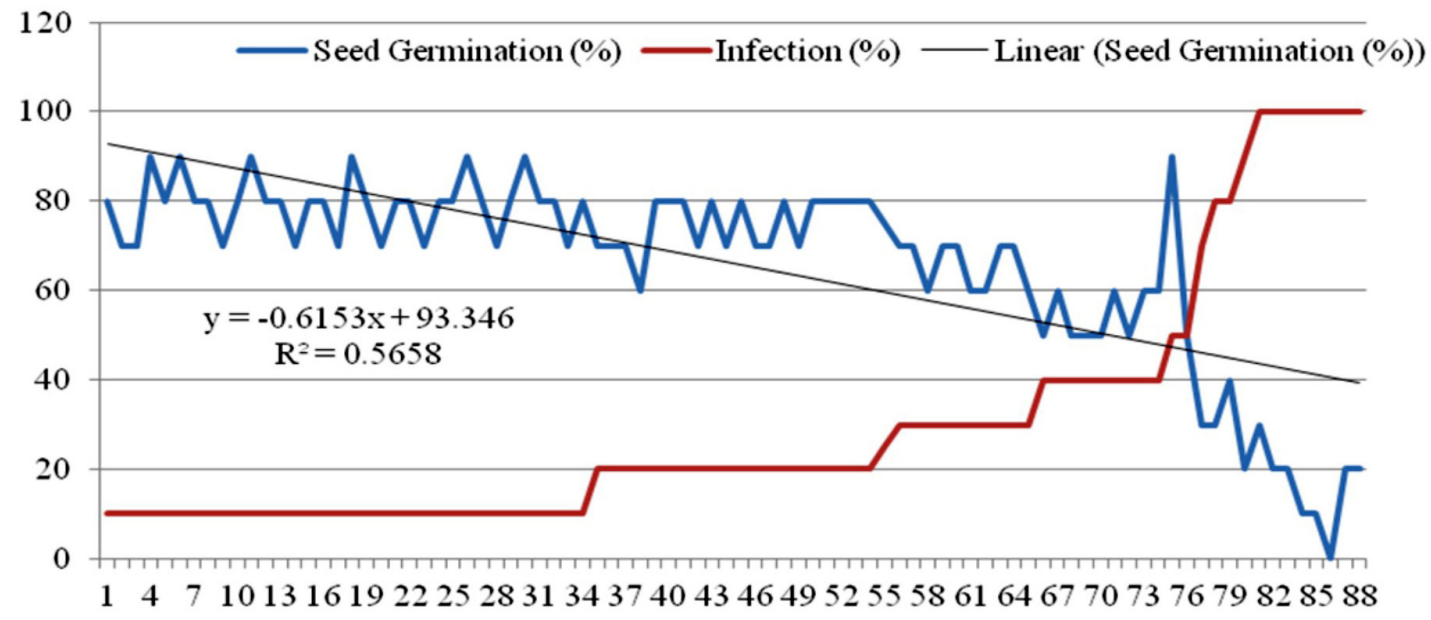

Fig. 4. Linear correlation between seed germination and infection of different fungi detected on medicinal and aromatic plants germplasm

on Coix lacryma-jobi, Costus speciosus, Ochna lanceolata, Perilla frutescens and Tagetus patula and $T$. cucumerina and Trichosanthes bracteata. Therefore, these medicinal and aromatic plants are new host records for the said fungi from India. Thus, our finding highlights the importance of pathogens detected on various MAPs germplasm.

Crop-wise infection revealed that $C$. speciosus is the most vulnerable to seed-borne fungi among MAPs assessed, which was recorded with nine fungal species i.e., Botrytis cinerea, Cephalosporium maydis, Fusarium semitectum, F. solani, F. verticillioides, Lasiodiplodia theobromae, Melanospora zamiae, Myrothecium verrucaria and Phoma sorghina followed by $T$. cucumerina and T. bracteata recorded with seven fungal species i.e., Fusarium oxysporum, F. solani, F. verticillioides, L. theobromae, Phoma exigua var. exigua, $P$. sorghina and Verticillium albo-atrum.

Accession-wise infection showed that IC-587520 of C. speciosus was recorded with highest infection/multiple infections of seven fungal species i.e., B. cinerea, $C$. maydis, F. semitectum, F. solani, F. verticillioides, $M$. zamiae and $P$. sorghina followed by IC-439154 with $B$. cinerea, F. semitectum, L. theobromae and M. verrucaria with varying degree of infection level. Location-wise analysis revealed that the maximum numbers of pathogenic fungal species (12) belonging to nine genera were detected on MAPs germplasm from Jharkhand state followed by Uttarakhand state where six fungal species belonging to three important genera on 11 accessions of four crop species of MAPs germplasm. The state of West Bengal was also recorded with five fungal species belonging to four genera from three accessions of two crop species. Therefore, MAPs germplasm may be comparatively more prone to fungal diseases in Jharkhand, Uttarakhand and West Bengal than other states (Table 1).

Out of the total 880 accessions of MAPs germplasm processed for SHT, pathogen-wise overall infection showed share of B. cinerea $(11.1 \%)$, F. oxysporum $(2.8 \%), F$. semitectum (5.6\%), F. solani $(5.6 \%), F$. verticillioides $(8.3 \%)$, L. theobromae $(8.3 \%)$, M. roridum (2.8), P. sorghina (19.4\%), U. coicis (44.4\%) and V. alboatrum (4.2\%) altogether in 71 infected accessions (8.1\%) (Fig. 3). 


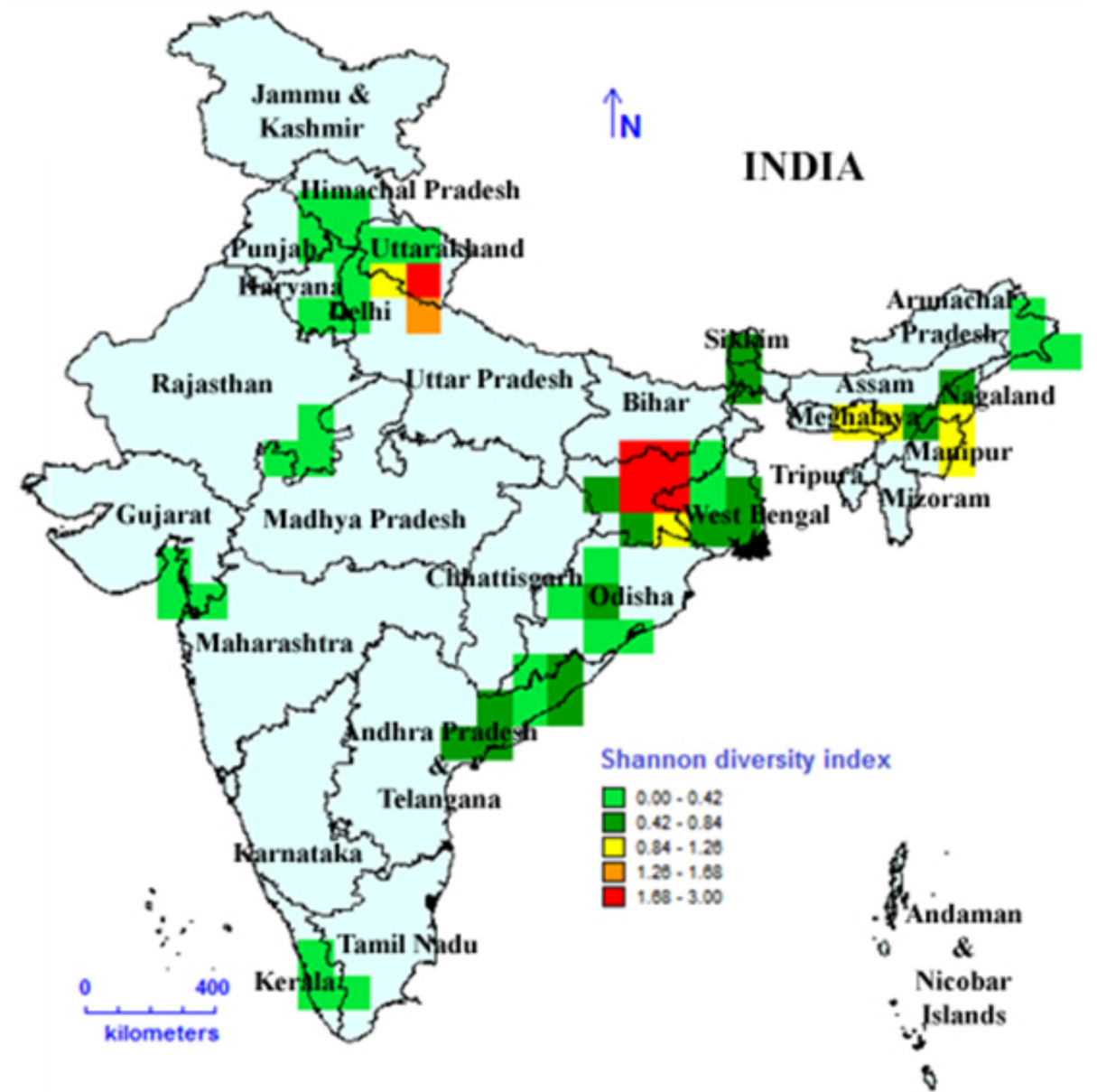

Fig. 5. Shannon's diversity index of fungal pathogens associated with medicinal and aromatic plants germplasm in India

Further, correlation analysis revealed that there is a significant negative correlation between the level of infection and seed germination with $r$ value -0.93 and $r^{2}$ value of 0.56 (Fig. 4). GIS based grid map was generated for showing the pathogens distribution in different states of the country. Colours of the grids are indicative of the extent of occurrence of the seed-borne fungal pathogens. Grid map generated revealed the highest pathogen richness in Jharkhand with 12 species belonging to nine fungal genera followed by Uttarakhand with six species belonging to three genera (Fig. 5).

Detection of such a large number of pathogens signifies the role of $\mathrm{SHT}$ in the safe conservation of these germplasm. These infected seeds could have been a source of inoculum and spread of the pathogen across the country and could have posed a serious threat to the medicinal and aromatic crops industry if these seeds are conserved and released for utilization in various crop improvement programmes for farmers. Therefore, the seed health testing has significant importance in conserving disease-free material for minimizing the risk of spreading disease in the country.

\section{ACKNOWLEDGEMENTS}

The authors are thankful to The Director, ICAR-NBPGR, New Delhi for providing facilities. The authors also acknowledge the help extended by the scientists and technical staff of Plant Quarantine Division in processing the samples for this study. Thanks are also acknowledged to Dr. Dinesh Prasad Semwal, Division of Germplasm Exploration, ICAR-NBPGR for developing pathogens diversity index map.

\section{REFERENCES}

Akhtar J, Kandan A, Singh B, Chand D, Kumar J and Agarwal PC (2014). Modified technique of obtaining pure cultures of seed-borne fungi. Indian J. PI. Protection 42: 156-159.

Barata AM, Rochaa F, Lopesa V and Carvalhoba AM (2016). Conservation and sustainable uses of medicinal and aromatic plants genetic resources on the worldwide for human welfare. Ind. Crops Prod. 88: 8-11.

CAB International (2007). Crop Protection Compendium (2007 ${ }^{\text {th }}$ Edition). Centre for Agriculture and Bioscience International. Wallingford, Oxon, UK.

Chandel S, Dubey K and Kaushal P (2014). Major diseases of medicinal and aromatic plants recorded in Himachal Pradesh, India. J. Pl. Dis. Sci. 9: 145-153.

Chavan SF and Korekar SL (2011). A survey of medicinal plants for fungal diseases from Osmanabad district of Maharashtra state. Recent Res. Sci. Technol. 3: 15-16.

Choudhary S (1946). Some studies on smut Ustilago coicis Bref. of Job's tears millet. J. Ind. Bot. Soc. 25: 123-130.

Dev U, Agarwal PC, Singh B, Chand D and Bhardwaj J (2010). Fungal pathogens intercepted in imported germplasm of medicinal and aromatic plant and their quarantine 
significance. In: Souvenir and Abstracts, National Conference on 'Biodiversity of medicinal and aromatic plants: collection, characterization and utilization. Medicinal and aromatic plants association of India, Anand, Gujrat. (TS3-03), pp. 60-61.

Gilbert RL (2003). First report of Exserohilum pedicellatum on Zea mays in Australia. Plant Pathol. 52: 404.

Gupta S, Dubey A and Singh T (2011). Fusarium semitectum as a dominant seed-borne pathogen in Dalbergia sissoo Roxb., its location in seed and its phytopathological effects. Indian Journal of Fundamental and Applied Life Sciences 1: 5-10.

Gupta V, Singh A, Singh BP and Parakh DB (2013). Medicinal plants used in local health care system of Chanawada village, Udaipur, Rajasthan (A case study). Int. J. PI. Sci. 8: 201-204.

Gure A, Slippers B and Stenlid J (2005). Seed-borne Botryosphaeria spp. from native Prunus and Podocarpus trees in Ethiopia, with a description of the anamorph Diplodia rosulata sp. Mycol. Res. 109: 1005-1014.

Gurib-Fakim A (2006). Medicinal plants: Traditions of yesterday and drugs of tomorrow. Mol. Aspects Med. 27: 1-93.

Hijmans RJ, Guarino L, Cruz M and Rojas E (2001). Computer tools for spatial analysis of plant genetic resources data: 1. DIVA-GIS. PI. Genet. Resour. Newslett. 127: 15-19.

Hong CF, Tsai SF, Yeh HC and Fan MC (2013). First report of Myrothecium roridum causing Myrothecium leaf spot on Dieffenbachia picta'Camilla' in Taiwan. Plant Dis. 97: 1253.

Ingle A and Rai M (2011). Genetic diversity among Indian phytopathogenic isolates of Fusarium semitectum Berkeley and Ravenel. Adv. Biosci. Biotechnol. 2: 142-148.

Irwin J, Singh S, Kochman J and Murray G (1999). Pathogen risks associated with bulk maize imports to australia from the United States of America. A report by technical working group 1: Disease risk analysis, for the import of maize from the USA for processing and use as animal feed. $126 \mathrm{p}$.

Janardhan KK, Ganguly D and Husain A (1964). Fusarium wilt of Rauvolfia serpentina. Curr. Sci. 33: 313.

Kiecana I, Cegie ${ }^{3}$ ko M and Mielniczuk E (2012). Fungi colonizing the swing material of turfgrasses considering susceptibility of cultivars to selected pathogens. Acta Sci. Pol. Hortorum Cultus 5: 153-168.

Magurran AE (1988). Ecological diversity and its measurement, Princeton University Press. Princeton, New Jersey, USA, p. 215.

Mahdizadeh V, Safaie N and Goltapeh EM (2011). Diversity of Macrophomina phaseolina based on morphological and genotypic characteristics in Iran. Plant Pathol. J. 27: 128137.

Mathe A (ed.) (2015). Medicinal and aromatic plants of the world. Scientific, Production, Commercial and Utilization Aspects. Springer Technology and Engineering. 460 p.

Mathur SB and Kongsdal O (2003). Common laboratory seed health testing methods for detecting fungi. International Seed Testing Association, Basserdorf, Switzerland. p 425.

Nelson SC (2008). Mango anthracnose (Colletotrichum gloeosporioides). J. Plant Dis. 48: 1-9.

Nwachukwu EO and Umechuruba CI (1996). Changes in nutritional values of African yam bean seeds due to seedborne fungi. Global J. Pure Appl. Sci. 3: 141-147.

Okunowo WO, Gbenle GO, Osuntoki AA and Adekunle AA (2010). Media studies on Myrothecium roridum Tode: A potential biocontrol agent for water hyacinth. J. Yeast Fungal Res. 1: 55-61.
Pande S, Galloway G, Gaur PM, Siddique KHM, Tripathi HS, Taylor P, MacLeod MWJ, Basandrai AK, Bakr A, Joshi S, Kishore KG, Isenegger DA, Rao NJ and Sharma M (2006). Botrytis grey mould of chickpea: A review of biology, epidemiology and disease management. Aust. J. Agric. Res. 57: 1137-1150.

Prabhu AS and Bedendo IP (1988). Glume blight of rice in Brazil: Etiology, varietal reaction and loss estimates. Trop. Pest Manage. 34: 85-88.

Punnithaligam E (1980). Plant diseases attributed to Botryodiplodia theobromae Pat. Bibliotheca Mycologia, London, v.71, p.1-123.

Raut AS, Kshirsagar DN, Kurade KC, More SW and Ingle ST (2016). Occurrence of major diseases on medicinal and aromatic plants and their relationship with weather parameters. Bioinfolet. 13: 409-419.

Richardson MJ (1990). An Annonated List of Seed-borne Diseases. Fourth Ed. International Seed Testing Association, Zurich, Switzerland, p. 387.

Samra AS, Sabet KA and Hingorani MK (1963). Late wilt disease of maize caused by Cephalosporium maydis. Phytopathology 53: 402-406.

Saremi H, Ammarellou A, Marefat A and Okhovvat SM (2008). Binam, a rice cultivar, resistant for root rot disease on rice caused by Fusarium moniliforme in Northwest Iran. Int. J. Bot. 4: 383-389.

Saremi H, Okhovvat SM and Ashrafi SJ (2011). Fusarium diseases as the main soil borne fungal pathogen on plants and their control management with soil solarization in Iran. J. Biotech. 10: 18391-18398.

Schippmann U, Leaman DJ and Cunningham AB (2002). Impact of cultivation and gathering of medicinal plants on biodiversity: Global trends and issues. In: Biodiversity and the ecosystem approach in agriculture, forestry and fisheries, Satellite event on the occasion of the Ninth Regular Session of the Commission on Genetic Resources for Food and Agriculture. Rome, 12-13 October 2002. InterDepartmental Working Group on Biological Diversity for Food and Agriculture, Rome. pp 1-21. (http://www.fao.org/ 3/contents/11fc3667-52a7-5192-8fbb-358daaeaf 558/ AA010E00.pdf)

Sharma DDK, Bharti YP, Singh PK, Shukla DN and Kumar A (2014). Studies on prevalence and identification of new races of Fusarium moniliforme Sheldon incitant of Pokkah boeng disease from Uttar Pradesh. Global Journal of Biology, Agriculture and Health Sciences 3: 53-61.

Sharma M and Kulshrestha S (2015). Colletotrichum gloeosporioides: an anthracnose causing pathogen of fruits and vegetables. Biosci. Biotechnol. Rese. Asia 12: 12331246.

Singh B, Akhtar J, Chand D, Sharma R, Kapoor ML and Agarwal PC (2014). Interception of Phoma sorghina on Transgenic Arabidopsis thaliana from USA- A New Host Record. Indian J. Plant Protec. 42: 89-90.

Sinha P, Govil JN and Singh NK (2002). Recent progress in medicinal plants: Diseases and their management. Science \& Technology Publishing LLC, USA. 212 p.

Titatarn S, Chiegkul A, Unchalisangkas D, Chamkrachang W, Chew-Chin N and Chandrasrikul A (1983). Occurrence of Ustilago coicis on Coix lacryma-jobi in Thailand. Plant Dis. 67: 434-435.

Yang Shaw-Ming (1995). Host range determination of Myrothecium verrucaria isolated from leafy spurge. Plant Dis. 79: 995-997. 